\title{
PERBEDAAN TEKANAN DARAH PADA AKSEPTOR KONTRASEPSI SEBELUM DAN SETELAH PEMAKAIAN KB SUNTIK 1 BULAN
}

\author{
Rofeny Agustin, Rachmawati, Elvi Destariyani \\ Politeknik Kesehatan Kementerian Kesehatan Bengkulu, Jurusan Kebidanan, \\ Jl. Indragiri Nomor 03 Padang Harapan Bengkulu \\ jmkbengkulu@gmail.com
}

\begin{abstract}
Increased blood pressure (hypertension) or decreased (hypotension) affect homeostasis in the body cause interference with the transport system of oxygen, carbon dioxide, and other metabolic outcomes. Hypertension is a cardiovascular disease prevalence and mortality is quite high, especially in the developed and developing countries. Data Riskedas 2007 the incidence of hypertension in Indonesia reached $31.7 \%$. Meanwhile, the data Bengkulu City Health Office incidence of hypertension as much as 30 According to IDHS (2012) the percentage of participants who experienced hypertension injectables is $0.5 \%$ of the number of acceptors. The study aimed to determine differences in blood pressure at the injection acceptors before and after the use of injectables 1 month. Design research is an analytic survey with cross sectional approach. The population is around the injection acceptors in Puskesmas Nusa Indah Bengkulu in 2013 as many as 604 people. The sample totaled 86 acceptors taken by purposive sampling. The data is then processed by univariate and bivariate analysis. From the results of 86 research note acceptors injecting 1 month, blood pressure injection acceptors 1 month before and after the use of injectables has average - average 9,070. Statistical tests obtained $p=0.000<\alpha=0.05$, that there are significant differences between the blood pressure before and after menggukan 1 month injectable contraceptive. For health care workers is expected to provide information and education to health 1 month injectable contraceptive acceptors.
\end{abstract}

Keywords: Blood Pressure, Injectable Contraceptive

\begin{abstract}
Abstrak : Tekanan darah meningkat (hipertensi) atau menurun (hipotensi) mempengaruhi homeostatis di dalam tubuh menyebabkan terjadinya gangguan sistem transportasi oksigen, karbondioksida, dan hasil-hasil metabolisme lainnya. Hipertensi merupakan penyakit kardiovaskuler dengan prevalensi dan kematian cukup tinggi terutama di negara maju dan berkembang. Data Riskedas tahun 2007 di Indonesia angka kejadian hipertensi mencapai 31,7\%. Sedangkan, data Dinkes Kota Bengkulu angka kejadian hipertensi sebanyak 30. Menurut SDKI (2012) presentase peserta KB suntik yang mengalami hipertensi adalah 0,5\% dari jumlah akseptor. Penelitian bertujuan untuk mengetahui perbedaan tekanan darah pada akseptor KB suntik sebelum dan setelah pemakaian KB suntik 1 bulan. Desain penelitian yang digunakan adalah survey analitik dengan pendekatan Cross Sectional. Populasi dalam penelitian adalah seluruh akseptor KB suntik di wilayah kerja Puskesmas Nusa Indah Bengkulu tahun 2013 yaitu sebanyak 604 orang. Sampel berjumlah 86 akseptor KB diambil secara purposive sampling. Data kemudian diolah dengan analisis univariat dan bivariat. Dari hasil penelitian diketahui dari 86 akseptor KB suntik 1 bulan, tekanan darah pada akseptor KB suntik 1 bulan sebelum dan setelah pemakaian KB suntik mempunyai rata - rata 9.070. Hasil pengujian statistik diperoleh $\mathrm{p}=0,000$ $<\alpha=0,05$, bahwa terdapat perbedaan yang signifikan antara tekanan darah sebelum dan setelah menggukan alat kontrasepsi suntik 1 bulan. Bagi petugas kesehatan diharapkan dapat memberikan informasi dan pendidikan kesehatan kepada akseptor kontrasepsi suntik 1 bulan.
\end{abstract}

Kata Kunci : Tekanan Darah, Suntik KB.

Tekanan darah merupakan faktor yang amat penting pada sistem sirkulasi. Peningkatan atau penurunan tekanan darah akan mempengaruhi homeostatis di dalam tubuh. Tekanan darah selalu diperlukan untuk daya dorong mengalirnya darah di dalam arteri, arteriola, kapiler dan sistem vena, sehingga terbentuklah suatu aliran darah yang menetap. 
Tekanan darah tinggi atau yang sering disebut dengan hipertensi, merupakan salah satu faktor risiko penyakit kardiovaskuler dengan prevalensi dan kematian yang cukup tinggi terutama di negara-negara maju dan di daerah perkotaan di negara berkembang, seperti halnya di Indonesia. Menurut Joint National Committee on Prevention, Detection, Evaluation, and Treatment on High Blood Pressure VII (JNC-VII), hampir 1 milyar orang menderita hipertensi di dunia. Menurut laporan World Health Organization (WHO), hipertensi merupakan penyebab nomor 1 kematian di dunia. Data tahun 2010 di Amerika Serikat menunjukkan bahwa $28,6 \%$ orang dewasa berusia 18 tahun ke atas menderita hipertensi. Sedangkan untuk populasi di Indonesia, angka kejadian hipertensi itu berdasarkan Riset Kesehatan Dasar (Riskedas) Departemen Kesehatan 2007 mencapai 31,7\%. Menurut Dinkes Kota Bengkulu tahun 2012, angka kejadian hipertensi sebanyak $30 \%$.

Tekanan darah tinggi dipengaruhi oleh beberapa faktor yaitu usia, stres, gaya hidup tak sehat seperti konsumsi garam berlebih, merokok dan konsumsi alkohol, kurang beraktifitas, pengaruh pemakaian kontra-sepsi suntik terhadap tekanan darah (Ethel, 2003). Sedangkan akibat dari peningkatan tekanan adalah gangguan pada fungsi ginjal, serangan jantung, stroke, glaukoma, disfung-si ereksi, penurunan daya ingat karena te-kanan tinggi pada reseptor otak akan melemahkan sistem neurotrasmiter penting yang bertugas menyimpan dan mengatur output memori, bahkan dapat menyebabkan kematian.

Penggunaan kontrasepsi hormonal yang secara teratur cukup mempengaruhi peningkatan tekanan darah terutama pada penggunaan kontrasepsi suntik 1 bulan. Menurut SDKI (2012) presentase peserta Keluarga Berencana (KB) suntik yang mengalami hipertensi adalah 0,5\% dari jumlah akseptor. Padahal Keluarga Berencana $(\mathrm{KB})$ meme-gang peranan penting untuk mengatur jarak kehamilan, mengatur jumlah kehamilan serta meningkatkan usia perkawinan dan hamil sampai mencapai masa reproduksi sehat (Hanafi, 2004).
Menurut BKKBN (2012), pengguna kontrasepsi suntik di Bengkulu yang mengalami kenaikan tekanan darah adalah $0,5 \%$ dari jumlah akseptor. Sedangkan akseptor kontrasepsi suntik 1 bulan yang mengalami kenaikan tekanan darah terbanyak di Puskesmas Nusa Indah Kota Bengkulu sebanyak 30\%. Dalam hal ini Puskesmas Nusa Indah Kota Bengkulu merupakan urutan ke empat akseptor kontrasepsi suntik dengan jumlah akseptor 1.512 orang dan urutan pertama pada dalam terjadinya hipertensi di Kota Bengkulu yaitu sebanyak 489 orang (Dinkes Kota Bengkulu, 2012).

Efek samping yang bisa terjadi dari $\mathrm{KB}$ suntik yaitu gangguan haid, depresi, keputihan, jerawat, perubahan libido, perubahan berat badan, pusing, sakit kepala, hematoma pada daerah suntikan, dan gangguan kardiovaskuler yang ditimbulkan akibat pemakaian KB suntik salah satunya dapat menurunkan High Density Lipo-protein-kolesterol (HDL-kolesterol) yang bisa menyebabkan terjadinya arterioskle-rosis. Adanya arteriosklerosis, maka lumen arteri akan semakin sempit. Selain itu arteriosklerosis akan menurunkan elastisitas dinding pembuluh darah arteri (Hartanto, 2004).

\section{BAHAN DAN CARA KERJA}

Penelitian ini adalah penelitian metode metode survey analitik menggunakan pende-katan potong silang. Populasi dalam penelitian ini adalah seluruh akseptor KB suntik di wilayah kerja Puskesmas Nusa Indah Bengkulu tahun 2013 yaitu sebanyak 604 orang. Jumlah sampel yang diambil dalam penelitian ini adalah 86 orang. Teknik pengambilan sampel adalah purposive sampling dimana pengam-bilan sampel ini dilakukan berdasarkan kriteria yang telah digunakan.

Pengumpulan data dilakukan dengan menggunakan data sekunder dan data primer. Data sekunder untuk melihat data nama, umur, alamat, lama penggunaan kontrasepsi suntik 1 bulan dan tekanan darah sebelum penggunaan KB suntik. Data primer dilakukan dengan cara observasi untuk mendapatkan data tekanan darah responden saat ini dengan menggunakan tensi darah dan stetoskop. 
Teknik pengumpulan data yang telah dilakukan dalam penelitian ini adalah dengan menentukan responden sebagai subyek sesuai kriteria, mencatat nama responden, mencatat umur responden, mencatat alamat responden, mencatat lama pemakaian $\mathrm{KB}$ suntik 1 bulan dan mencatat tekanan darah sebelum pemakaian KB suntik 1 bulan. Peneliti selanjut-nya mendatangi rumah masing-masing responden untuk melakukan observasi tekanan darah. Sebelum melakukan observasi, peneliti menjelaskan terlebih dahulu tentang tujuan dan manfaat penelitian yang dilakukan, kemudian meminta kesediaan responden untuk menandatangani lembar persetujuan responden (informed consent). Selanjutnya melakukan observasi dengan cara menanyakan nama ibu untuk memastikan kebenaran nama responden, menanyakan umur responden, pekerjaan responden, mengukur tekanan darah responden dan menanyakan lama pemakaian kontrasepsi suntik satu bulan kepada responden. Hasil observasi dicatat pada lembar observasi. Analisis data dilakukan untuk melihat ada perbedaan tekanan darah pada akseptor kontrasepsi sebelum dan setelah pemakaian KB satu bulan menggunakan uji $\mathrm{T}$ dengan tingkat kepercayaan $95 \%$ dan taraf signifikan dengan tingkat kepercayaan 5\% $(0,05)$ menggunakan sistem komputerisasi.

\section{HASIL}

Tabel 1. Gambaran Rata-Rata Lama Penggunaan Kontrasepsi pada Akseptor KB Suntik Satu Bulan

\begin{tabular}{lcllll}
\hline \multicolumn{1}{c}{ Variabel } & Mean & Min & Max & SE & SD \\
& & & & & \\
\hline Lama & 7.02 & 4 & 12 & 0.02 & $\mathbf{2 . 2}$ \\
\hline
\end{tabular}

Berdasarkan Tabel 1 didapatkan nilai ratarata lama penggunaan kontrasepsi pada akseptor KB suntik 1 bulan adalah 7,02 yang berarti lama penggunaan kontrasepsi suntik rata-ratanya adalah 7 bulan. Minimal lama penggunaan kontrasepsi suntik 1 bulan adalah selama 4 bulan, dan maksimal lama penggunaan kontrasepsi suntik 1 bulan adalah selama 12 bulan.
Tabel 2. Gambaran rata-rata tekanan darah sebelum dan setelah pemakaian kontrasepsi pada akseptor KB suntik 1 bulan

\begin{tabular}{lccccc}
$\begin{array}{c}\text { Tekan Darah } \\
\text { Systole }(\mathbf{m m H g})\end{array}$ & Mean & Min & Max & SE & SD \\
& & & & & \\
\hline Sebelum & 109.07 & 100 & 120 & 0.76 & 7.13 \\
Sesudah & 118.14 & 100 & 130 & 0.74 & 6.94 \\
\hline
\end{tabular}

Nilai rata-rata tekanan darah sebelum pemakaian KB suntik 1 bulan adalah 109,07 yang berarti tekanan darah sebelum penggunaan kontrasepsi suntik rata-ratanya adalah 109 mmHg. Minimal tekanan darah sebelum penggunaan kontrasepsi suntik 1 bulan adalah $100 \mathrm{mmHg}$, dan maksimal tekanan darah setelah penggunaan kontrasepsi suntik 1 bulan adalah $120 \mathrm{mmHg}$.

Nilai rata-rata tekanan darah setelah pemakaian KB suntik 1 bulan adalah 118,14 yang berarti tekanan darah setelah penggunaan kontrasepsi suntik rataratanya adalah 118 mmHg. Minimal tekanan darah setelah penggunaan kontrasepsi suntik 1 bulan adalah $100 \mathrm{mmHg}$, dan maksimal tekanan darah setelah penggunaan kontrasepsi suntik 1 bulan adalah $130 \mathrm{mmHg}$.

Tabel 3. Perbedaan rata-rata tekanan darah pada akseptor kontrasepsi sebelum dan setelah KB suntik 1 bulan

\begin{tabular}{lcccc}
\hline $\begin{array}{c}\text { Tekanan } \\
\text { Darah }\end{array}$ & Mean & SE & T & $\boldsymbol{p}$ \\
\hline $\begin{array}{l}\text { Sebelum } \\
\text { Setelah }\end{array}$ & -9.070 & 0.539 & -16.820 & 0.000 \\
\hline * Uji Analisis : T Test & & & \\
\hline
\end{tabular}

Berdasarkan tabel 3 diketahui bahwa dari 86 akseptor kontrasepsi suntik 1 bulan, perbedaan rata - rata tekanan darah sebelum dan setelah penggunaan $\mathrm{KB}$ suntik 1 bulan sebesar $-9,070$ dengan nilai $p 0,000<\alpha 0,05$ ini berarti terdapat perbedaan yang signifikan terhadap tekanan darah sebelum dan setelah penggunaan alat kontrasepsi suntik 1 bulan.

\section{PEMBAHASAN}

Hasil penelitian didapatkan ada perbedaan yang signifikan pada tekanan darah sebelum dan setelah penggunaan alat kontrasepsi suntik 1 bulan dengan nilai $p=0,000<\alpha=0,05$. Hal ini menunjukkan bahwa ada peningkatan tekanan darah sebelum dan setelah penggunaan alat kontrasepsi suntik 1 bulan yang berarti KB 
suntik 1 bulam berpengaruh dalam meningkatkan tekanan darah.

Hasil penelitian menunjukkan nilai ratarata nilai rata-rata tekanan darah sebelum pemakaian KB suntik 1 bulan adalah 109,07 yang berarti tekanan darah sebelum penggunaan kontrasepsi suntik rata -ratanya adalah $109 \mathrm{mmHg}$. Sedangkan nilai rata-rata tekanan darah setelah pemakaian KB suntik 1 bulan adalah 118,14 yang berarti tekanan darah setelah penggunaan kontrasepsi suntik rataratanya adalah $118 \mathrm{mmHg}$. Hal ini menunjukan bahwa tekanan darah mengalami peningkatan, dengan kenaikan systole 10 . Sebanyak 78 orang $(90,7 \%)$ akseptor KB Suntik 1 bulan di Puskesmas Nusa Indah kota Bengkulu sebagian besar mengalami peningkatan tekanan darah.

Rata-rata yang mengalami peningkatan tekanan darah merupakan akseptor yang telah memakai KB Suntik 1 bulan selama 4-12 bulan, yang tidak mempunyai tekanan darah tetap telah memakai $\mathrm{KB}$ suntik 1 bulan selama 4-11 bulan. Sedangkan yang memiliki tekanan darah menurun telah menggunakan $\mathrm{KB}$ suntik 1 bulan selama 4 bulan. Hal ini kemungkinan terjadi karena aktifitas, pekerjaan, stress dan usia responden. Saat penelitian ini dilakukan, hampir semua responden merupakan ibu rumah tangga dan wanita usia 25 - 38 tahun. Hampir seluruh ibu rumah tangga mengatakan bahwa mengalami stress karena sibuk mengerjakan pekerjaan rumah, mengurus keluarga, dan sedikit memiliki waktu istirahat.

Hasil penelitian ini sejalan dengan penelitian yang dilakukan Runiari, dkk (2012), hasilnya ada perbedaan yang signifikan antara tekanan darah sebelum dan setelah pemakaian KB suntik 1 bulan. Hasil penelitiannya menunjukkan bahwa responden yang memakai kontrasepsi suntikan $\geq 3$ bulan memiliki tekanan darah yang tergolong pre-hipertensi yaitu $68,8 \%$ dengan uji statistik $p=0,018$ yang dapat disimpulkan bahwa ada perbedaan yang signifikan antara tekanan darah sebelum dan setelah pemakaian KB suntik 1 bulan.

Hasil penelitian ini juga sesuai dengan teori Wiknjosastro (2007), bahwa pemakaian kontrasepsi suntik dapat mempengaruhi kenaikan tekanan darah karena meningkatkan kejadian tromboemboli dan gangguan pembuluh darah otak. Tromboemboli terjadi akibat perubahan sistem pembekuan darah akibat estrogen, disamping efek aterosklerosis oleh pengaruh progesteron. Risiko tromboemboli dapat dipengaruhi oleh lamanya pemakaian suntik. Tekanan darah tinggi (hipertensi) dapat terjadi pada 5\% pemakai KB suntik.

Penelitian ini didukung juga oleh teori Hamman, dkk (2004) yang mengatakan bahwa penggunaan KB suntik 1 bulan dapat meningkatkan tekanan darah disebabkan karena peningkatan tekanan darah secara teratur berkolerasi dengan perubahan paralel reninangiotensin-aidosteron system dan disebabkan oleh komponen estrogen pada kontrasepsi hormonal, sehingga menyebabkan vasokontriksi pembuluh darah dan peningkatan produksi aldosteron yang menyebabkan peningkatan tekanan darah sistemik.

Tekanan darah merupakan daya dorong ke semua arah pada seluruh permukaan yang tertutup pada dinding bagian dalam jantung dan pembuluh darah untuk menggerakkan darah keseluruh tubuh (Ethel, 2003). Efek cyclofem pada sistem kardiovaskuler menyebabkan adanya sedikit peninggian dari kadar insulin dan penurunan HDL-kolesterol. Kolesterol tidak larut dalam air ataupun darah. Kolesterol diangkut ke berbagai jaringan dalam tubuh dengan bantuan senyawa yang tersusun atas lemak dan protein yaitu lipoprotein. Kolesterol LDL (low density lipoprotein) cenderung tersimpan dalam arteri. Kondisi ini berakibat buruk karena jika kadar kolesterol LDL > 130 $\mathrm{mg} / \mathrm{dl}$ sedangkan HDL mengalami penurunan yaitu $<40 \mathrm{mg} / \mathrm{dl}$ maka ini merupakan risiko akan terjadi peningkatan tekanan darah (Hartanto, 2004).

Teori Varney (1993) juga berpendapat bahwa efek samping dari kandungan hormon progesteron yang berlebihan pada sistem kardiovaskuler dapat menyebabkan perubahan tekanan darah. Resiko terjadinya tekanan darah tinggi akan meningkat dengan bertambahnya umur, lama pemakaian kontrasepsi dan bertambahnya berat badan.

Faktor lain yang mempengaruhi peningkatan tekanan darah seperti usia, stress dan 
aktifitas fisik. Tekanan darah akan lebih meningkat saat melakukan aktifitas fisik dan lebih rendah pada saat istirahat. Hal ini juga berkaitan dengan aktifitas sebagian besar ibu rumah tangga yang selalu sibuk dengan pekerjaan rumah, sehingga kemungkinan didapatkan tekanan darah yang lebih tinggi saat dilakukan observasi. Tekanan darah juga akan meningkat seiring dengan bertambahnya usia karena estrogennya masih tinggi. Wanita yang belum mengalami menopause dilindungi oleh hormon estrogen yang berperan dalam meningkatkan kadar Kadar High Density Lipoprotein (HDL). Sedangkan Kadar High Density Lipoprotein (HDL) yang tinggi merupakan faktor pelindung dalam mencegah terjadinya aterosklerosis. Pengurangan estrogen dapat terjadi lebih cepat oleh berbagai faktor seperti pemakaian kontrasespsi suntik 1 bulan karena efek dari cyclofem yang menurunkan High Density Lipoprotein-kolesterol (HDL kolesterol). Ada responden yang umurnya masih tergolong muda, sehingga kecenderungan untuk mengalami hipertensi lebih sedikit, tetapi peningkatan tekanan darah tetap terjadi secara berkala walaupun peningkatannya tetap di batas normal.

Faktor stres kemungkinan dipengaruhi oleh pekerjaan, dimana responden pada penelitian ini kebanyakan merupakan ibu rumah tangga yang kemungkinan tingkat stresnya cukup tinggi dengan pekerjaan yang banyak serta kejenuhan yang dialami ketika tinggal dirumah (Ethel, 2003).

Berdasarkan hasil penelitian yang didapatkan dari 86 akseptor KB suntik 1 bulan, hampir seluruh akseptor mengalami peningkatan tekanan darah setelah menggunakan KB

\section{DAFTAR RUJUKAN}

Arrum, Setya. (2011). Panduan Lengkap Pelayanan KB Terkini. Yogyakarta : Medical Book.

BKKBN. (2008). Kependudukan, Keluarga Berencana, dan Keluarga Sejahtera. Jakarta.

Boedhi-Darmojo. (2003). Mengamati perjalanan epidemiologi hipertensi di Indonesia. Yogyakarta : Medika.

Crea, D. (2008). Kardiovaskuler. Jakarta : Medika.

Dinas Kesehatan Kota Bengkulu. (2012). Profil Kesehatan Kota Bengkulu 2012. Bengkulu : Dinkes. suntik 1 bulan. Peningkatan ini meliputi peningkatan tekanan darah systole. Namun hal ini dapat disebabkan banyak faktor yang mungkin mempengaruhi peningkatan tekanan darah akseptor KB suntik 1 bulan seperti yang dikemukakan oleh Kozier (2003) bahwa faktor kemungkinan yang mempengaruhi peningkatan tekanan darah adalah usia, stres, gaya hidup tidak sehat dan aktivitas yang kurang. Tekanan darah systole maksimum setelah pemakaian kontrasepsi suntik 1 bulan dari penelitian ini adalah $130 \mathrm{mmHg}$. Hal ini responden masih diperbolehkan untuk menggunakan kontrasepsi suntik karena seperti pendapat Arum (2011) bila tekanan darah 140/90-180/110 $\mathrm{mmHg}$ dapat diberikan tetapi perlu pengawasan, bila tekanan darah $>180 / 110$ anjurkan klien ganti kontrasepsi non hormonal.

\section{KESIMPULAN}

Berdasarkan hasil penelitian ini dapat disimpulkan rata-rata lama penggunaan kontrasepsi pada akseptor KB suntik 1 bulan di wilayah kerja Puskesmas Nusa Indah Kota Bengkulu adalah 7 bulan. Rata-rata tekanan darah sebelum dan setelah pemakaian kontrasepsi suntik 1 bulan pada akseptor KB suntik di wilayah kerja Puskesmas Nusa Indah Kota Bengkulu adalah $109 \mathrm{mmHg}$ dan $118 \mathrm{mmHg}$. Rata-rata perbedaan tekanan darah sebelum dan setelah pemakaian KB suntik 1 bulan adalah 9,070 dengan nilai $p=0,000<\alpha=0,05$ yang berarti ada perbedaan tekanan darah sebelum dan setelah pemakaian KB suntik 1 bulan. Tekanan darah setelah pemakaian KB suntik lebih tinggi dari tekanan darah sebelum pemakaian KB suntik.

Everett, S. (2012). Kontrasepsi dan Kesehatan Seksual Reproduktif. Jakarta : EGC.

Ethel, R. (2003). Mengenal, Mencegah, Mengatasi Silent Killer Hipertensi. Semarang : Pustaka Widyamara.

Gray HH, Dawkins KD, Morgan JM \& Simpson IA. (2005). Kardiologi. Jakarta : Erlangga.

Hartanto, H . (2004) . Keluarga Berencana dan Kontrasepsi . Jakarta : Pustaka Sinar Harapan.

Hamman, dkk. (2004). Kontrasepsi Hormon dan Hipertensi. Jakarta. 
50 Jurnal Media Kesehatan, Volume 8 Nomor 1, April 2015, hlm 01-99

Kozier, E. (2003). Buku Ajar Praktik Keperawatan Klinis. Jakarta : Penerbit Buku Kedokteran EGC. Hipertensi. http://wikipedia.com.html. Diakses pada tanggal 1 Oktober 2013.

Leatham. (2003). Epidemiologi Hipertensi. Yogyakarta : Kanisius.

Notoadmojo, S. (2005). Metode Penelitian Kesehatan. Jakarta : Rineka Cipta

Price. (2005). Penatalaksanaan Faktor-faktor Risiko Kardiovaskuler pada

Penderita Hipertensi. Jakarta : Medika.

Rohaendi. (2008). Hipertensi dan Obesitas. Jakarta : Salemba Medika.

Runiari, dkk. (2012). Hubungan Antara Lama Pemakaian Kontrasepsi Suntik Progestin (Depoprovera) Dengan Tekanan Darah Pada Akseptor KB Di Puskesmas II Denpasar Selatan. Denpasar. Jurnal Ilmiah Kesehatan Keperawatan, Volume 8, No. 1, Februari 2012.
Saifuddin. (2007). Panduan Praktis Pelayanan Kontrasepsi. Jakarta: Yayasan Bina Pustaka.

Sorensen, dkk. (2003). Long Term Use Of Contraceptive Depo Medroxyprogesteron Acetate In Young Women Impairs Arterial Endhotelial Function Assessed By Cardiovascular Magnetic Resonance. Journal Of Family Planning \& Reproductive Health Care, jan2003, vol.29 issue 1.

Suryati, teti. (2013). Dampak Dan Bahaya Dari Penyakit Hipertensi. http://agromedia.net/artikel/dampakdan-bahaya-dari-penyakit hipertensi.html. diakses pada tanggal 11 maret 2014.

Winkjosastro. (2007). Buku Ajar Ilmu Kandungan. Jakarta: Yayasan Bina Pustaka

Yeni, dkk. (2009). Faktor-Faktor Yang Berhubungan Dengan Kejadian Hipertensi Pada Wanita Usia Subur Di Puskesmas Umbulharjo I Yogyakarta Tahun 2009. Yogyakarta. Jurnal Kesmas UAD.Vol. 4. No. 2, juni 2010. 